Сухомлинський, 1976 - Сухомлинський В. О. Проблеми виховання всебічно розвиненої особистості / В. О Сухомлинський // Вибр. тв.: у 5 т. - К.: Рад. шк., 1976. - Т.1. - С. 55-206.

Сухомлинський, 1962 - Сухомлинський В. О. Праця і моральне виховання / В. О. Сухомлинський. - К.: Рад. шк., 1962. - С. 51, 131.

Сухомлинський, 1967 - Сухомлинський В. О. Вибрані твори : в 5 т. / В. О. Сухомлинський. - К. : Рад. шк., 1976. - T. 4. - 1976. - 640 с.

Сухомлинський, 1977 - Сухомлинський В. О. Вибрані твори в п’яти томах / В. О. Сухомлинський. - Т. 3. -К. : Рад. Школа, 1977. - 707 с.

Сухомлинський. 1976 - Сухомлинський В. О. Проблеми виховання всебічно розвиненої особистості / В. О. Сухомлинський // Вибр. твори : в 5 т. - К. : Рад. школа, 1976. - Т. 1. - С. 5-402.

\title{
REFERENCES
}

Bekh, 2004 - Bekh I. D. Pedahohika serdechnosti V. O. Sukhomlynskoho / I. D. Bekh // Naukovyi visnyk Mykolaivskoho derzhavnoho universytetu. Pedahohichni nauky: zb. naukovykh prats. Vypusk № 8. Mykolaiv : MOU, 2004. - S.18.

Slovnyk ukrainskoi movy, 1971 - Slovnyk ukrainskoi movy: v 11 tomakh. - Tom 2, 1971. - S. 445.

Sukhomlynskyi, 1976 - Sukhomlynskyi V.O. Problemy vykhovannia vsebichno rozvynenoi osobystosti / V.O. Sukhomlynskyi // Vybr. tv.: u 5 t. - K.: Rad. shk., 1976. - T.1. - S. 55-206.

Sukhomlynskyi, 1962 - Sukhomlynskyi V.O. Pratsia i moralne vykhovannia / V.O. Sukhomlynskyi. - K.: Rad. shk., 1962. - S. 51, 131.

Sukhomlynskyi, 1967 - Sukhomlynskyi V. O. Vybrani tvory : v 5 t. / V. O. Sukhomlynskyi. - K. : Rad. shk., 1976. T. 4. $-1976 .-640 \mathrm{~s}$.

Sukhomlynskyi, 1977 - Sukhomlynskyi V. O. Vybrani tvory v piaty tomakh / V. O. Sukhomlynskyi. - T. 3. - K. : Rad. Shkola, 1977. - 707 s.

Sukhomlynskyi. 1976 - Sukhomlynskyi V. O. Problemy vykhovannia vsebichno rozvynenoi osobystosti / V.O. Sukhomlynskyi // Vybr. tvory : v 5 t. - K. : Rad. shkola, 1976. - T. 1. - S. 5-402.

Світлана Танана,

кандидат педагогічних наук, дочент кафедри професійної освіти

ДВНЗ «Переяслав-Хмельницький

державний педагогічний університет імені Григорія Сковороди».
Svitlana Tanana,

Ph.D. in Pedagogy, Associate Professor of the Department of Professional Education,

SHEI «Pereiaslav-Khmelnytskyi

Hryhorii Skovoroda

State Pedagogical University».

E-mail: tananasvetlana@gmail.com

ORCID 0000-00026088-0738

\section{ФОРМУВАННЯ КОМУНІКАТИВНОЇ КОМПЕТЕНТНОСТІ МАЙБУТНІХ ТОВАРОЗНАВЦІВ У ПРОЦЕСІ ЗАСВОСННЯ ДИСЦИПЛІН ФАХОВОГО СПРЯМУВАННЯ}

У статті досліджено теоретичні питання та особливості формування комунікативної компетентності майбутніх товарознавців у процесі засвоєння дисииплін фахового спрямування у закладах вищої освіти. Доведено, що формування комунікативної компетентності майбутніх товарознавців передбачає оволодіння навичками усвідомленого спілкування у межах науково-дослідної, організаційноуправлінської, виробничо-технологічної та професійної галузей, а врахування окреслених особливостей сприятиме ефективному формуванню комунікативної компетентності майбутнього товарознавия. Визначено: для ефективного виконання професійної діяльності товарознавці повинні мати не лише інтегровані фахові знання та вміти їх використовувати, а й досконало володіти знаннями гуманітарного циклу, оскільки людина водночас є як суб'єктом, так $і$ об'єктом нерозривно пов'язаного зі спілкуванням процесу управління. Акиентовано на специфічних особливостях формування комунікативної компетентності товарознавців, виявлено взаємозв'язок гуманітарних $і$ фахових дисииплін. Професійні якості, як мобільність, комунікабельність та діловитість майбутніх товарознавців, надзвичайно пов'язані $з$ його професійною успішністю, яка виявляється в багатьох показниках, а саме: у професійній компетентності, постійному фаховому та особистісному зростанні. 
Ключові слова: компетентність, майбутні товарознавці, комунікаційні взаємодії, професійні якості, мобільність, комунікабельність, професійна успішність.

The theoretical questions and peculiarities of formation of communicative competence of future merchandisers in the process of learning disciplines of professional directing at the higher educational establishment are researched. The formation of communicative competence of future merchandisers researchers involves mastering the skills of informed communication within the limits of scientific research, organizational-managerial, productiontechnological and professional branches, and taking this peculiarities will contribute to the effective formation of the communicative competence of the future merchandiser is proved in it. It is determined: for the effective execution of professional activity of merchandisers should have not only integrated professional knowledge and be able to use them, and also have a thorough knowledge of the humanitarian cycle, but the person at the same time is the subject and the object of the inextricably linked communication management process. On the specific peculiarities of formation of the communicative competence of merchandisers is adviced, and the relationship between humanitarian and professional disciplines is identified. Professional qualities, such as mobility, sociability and business of future merchandisers, are extremely related to his professional success, which is manifested in many indicators, namely: professional competence, constant professional and personal growth.

Keywords: competence, future merchandisers, communication interactions, professional qualities, mobility, professional achievement.

Постановка проблеми. Пріорітетними напрямами розвитку освітньої галузі України $є$ підвищення якості професійної підготовки педагогічних кадрів, стимулювання їхнього професійного становлення та розвитку. Сучасні соціальноекономічні умови й динамічні трансформації в освіті вимагають від випускника закладу вищого закладу високого рівня професіоналізму, творчого підходу до професійної діяльності, професійної активності та здатності навчатися впродовж усього життя. Нова концепція знання потребує змін педагогічних засобів його передачі, а відтак вимагає відповідної підготовки фахівців, здатних на теоретичному i практичному рівнях відповідати викликам часу, потребам глобалізованого суспільства, запитам сучасної освітньої реальності.

Підтвердження актуальності проблеми віднайдено в низці нормативних документів (Закон України «Про вищу освіту», Національна доктрина розвитку освіти України у XXI столітті, закон України «Про освіту»), де визначено вимоги до професійної компетентності вчителя. У Національній стратегії розвитку освіти в Україні на 2012-2021 pр. наголошується, що «сучасний ринок праці вимагає від випускника не лише глибоких теоретичних знань, а i здатності самостійно застосовувати їх у нестандартних, постійно змінюваних життєвих ситуаціях, переходу від суспільства знань до суспільства життєво компетентних громадян».

Про необхідність розвитку комунікативної компетентності майбутнього фахівця зафіксовано в Національній доктрині розвитку освіти (2002), Державній національній програмі «Освіта. Україна XXI століття» (2002), Загальноєвропейських рекомендаціях із мовної освіти (2001), Концепції розвитку економічної освіти в Україні (2003), законі України «Про освіту» (2017), Концепції розвитку професійної освіти і навчання в Україні (2010-2020), Національній стратегї̈ розвитку освіти в Україні (2012-2021).

Аналіз останніх досліджень і публікацій. Аналіз довідникової та наукової літератури засвідчив, що проблему професійної підготовки у вищій школі досліджено вітчизняними науковцями в різних аспектах, а саме: філософія вищої освіти (В. Андрущенко, І. Зязюн, В. Кремень, В. Огнев'юк); неперервна професійна освіта (С. Гончаренко, Н. Ничкало, С. Сисоєва); професійної підготовки майбутніх фахівців в умовах вищого навчального закладу (А. Алексюк, В. Бондар, С. Караман), зокрема економічного профілю (Н. Бутенко, Т. Поясок, С. Соболєва); формування 
професійної компетентності майбутніх фахівців (Н. Бібік, О. Пометун, О. Савченко, В. Ягупов); розгляду мовленнєвої компетентності фахівців у різних видах професійної діяльності (І. Кочан, М. Лісовий, С. Максименко, Л. Мацько, В. Пасинюк та ін.).

Mета статmi полягає у визначенні організаційно-методичних основ формування комунікативної компетентності майбутніх товарознавців у процесі засвоєння дисциплін фахового спрямування.

Виклад основного матеріалу. Комунікативна компетентність вчителя $\epsilon$ необхідною умовою ефективної комунікативної діяльності (може бути виміряна та оцінена), а професійна комунікативна компетентність учителя - це особистісне утворення, яке не є сталою категорією і не може бути виміряне за допомогою мовних тестів [Кічук, 2005: с. 48].

Реалізація компетентнісного підходу в контексті вищої освіти спрямована на підготовку фахівця відповідної галузі, спроможного здійснювати поставлену мету творчо й динамічно, використовуючи отримані знання в умовах, які потребують прийняття та реалізації нестандартних рішень. Модернізація освіти на компетентнісній основі «передбачає цілісний досвід розв'язання життєвих проблем, виконання ключових функцій, соціальних ролей, компетенцій» [Корніяка, 2009: c. 187].

У сучасній вітчизняній освіті визначився компетентнісний підхід, пов'язаний iз пошуком нових концептуально-методологічних засад, моделей підготовки фахівців із вищою професійною освітою, переосмисленням наявних державних освітніх стандартів. Такий перехід зумовлений об'єктивними причинами, оскільки процеси інтеграції, глобалізації, прискорені темпи змін соціально-економічних умов життя, зростання обсягу інформації спонукають до перегляду вимог якості підготовки спеціалістів із вищою освітою.

Нині компетентнісний підхід $є$ не лише перспективним, а й таким, який реально відповідає вимогам сучасності. Тенденція зміни знаннєвої освітньої педагогіки на компетентнісну є загальносвітовою й викликана новими економічними вимогами, оскільки «вимагає виховання самостійних, ініціативних і відповідальних членів суспільства, здатних адекватно взаємодіяти у виконанні соціальних, виробничих та економічних завдань» [Касярум, 2011: с. 14].

Ученими розроблено структуру професійної комунікативної компетентності педагога, що є похідною від структури комунікативної компетентності особистості, яка складається 3 п'яти компонентів - індивідуально-особистісного, мовленнєвого, інтерактивно-практичного, полікультурного та предметно-інформаційного, що включають складові комунікативної компетентності, базис яких становлять компетенції, що містять комунікативні знання, уміння, навички, ціннісні ставлення та орієнтири.

Прибічники компетентнісного підходу доводять, що компетентність - це інтегрована характеристика якості особистості, результативний блок, сформований через досвід, знання, вміння, ставлення, поведінкові реакції, або ж спеціально структуровані (організовані) набори знань, умінь, навичок і ставлень, що їх набувають у процесі навчання, які дозволяють людині визначати та розв'язувати, незалежно від ситуації, проблеми, притаманні певній царині діяльності [Бусел, 2005: c. 489]. Експерти Ради Європи вважають, що, оволодівши відповідними компетентностями, які охоплюють певний рівень знань, умінь, ставлень, людина зможе здійснювати поліфункціональні, поліпредметні, культуродоцільні види 
діяльності; ефективно розв'язувати відповідні проблеми, тобто стати спеціалістом, здатним реагувати на нові запити часу [Корніяка, 2009: с. 188].

Відповідно до завдань нашого дослідження важливо уточнити сутність використовуваних дефініцій i визначити на основі зіставлення, порівняння й узагальнення наукової інформації, скорегувати понятійну базу та конкретизувати поняття, часто вживані як синонімічні.

Так, укладачі сучасного словника іншомовних слів термін «компетентність» витлумачують у двох варіантах: володіння компетенцією; володіння знаннями і навичками, що дозволяють оцінювати що-небудь [Бусел, 2005: c. 328]. Автори «Великого тлумачнного словника української мови» так пояснюють сутність поняття «компетенції»: «питання, у яких будь-хто зможе повною мірою й у соціально значущих аспектах іiі реалізувати» [Касярум, 2015: c. 24]. Беручи до уваги наведені визначення, можемо стверджувати, що компетентність $\epsilon$ якісним показником освітнього процесу.

У процесі визначення основних психологічних та педагогічних чинників формування комунікативної компетентності необхідно виходити з того, що студенти повинні оволодіти цією професійною здатністю в умовах ЗВО. За інших обставин у майбутній професійній діяльності - їм доведеться опановувати нею самотужки, оскільки знання й уміння $є$ взаємозалежними частинами структури будь-якої діяльності.

Ураховуючи підходи до розкриття формування комунікативної компетентності педагогами, що досліджують проблеми професійної освіти, виокремлено такі загальні аспекти, на яких наголошує більшість науковців: залучення теоретичних професійних знань у реальну навчальну діяльність студента як способу досягнення мети у формуванні комунікативної компетентності; сприяння творчому застосуванню науково-теоретичних знань i практичних навичок із гуманітарних та спеціальних дисциплін; забезпечення продуктивної взаємодії в навчальному процесі, що є запорукою розвитку комунікативних умінь; успішний соціальний досвід та професійне самовизначення особистості.

Вважаємо, що такий підхід до формування комунікативної компетентності 3 урахуванням психологічних чинників та аспектів педагогічної специфіки сприятиме розвитку пізнавального інтересу майбутніх товарознавців.

Рівень професійної підготовки товарознавців $є$ найважливішим чинником забезпечення взаємозв'язків між безпосереднім впливом на культуру виробництва та якістю результатів роботи. Відповідно, культура виробничих відносин та результати діяльності товарознавця знаходяться у прямій залежності від рівня сформованості комунікативної компетентності фахівця.

Тому перехід зі статусу студента у статус фахівця супроводжується змінами у спрямуванні діяльності, професійній відповідальності. Адже, якщо навчальна діяльність передбачає оволодіння знаннями й отримання вмінь та навичок, то на практиці основними видами діяльності товарознавців є планування, організація, координація та контроль.

Комунікативна компетентність товарознавців є основою життєзабезпечення кожної організації, підприємства, являє живу тканину діяльності, потребує чіткого орієнтування у професійній ситуації, відбору тих засобів спілкування, які є найбільш ефективними.

Зауважимо, що специфіка комунікативної компетентності професійного навчання зумовлена предметом майбутньої професійної діяльності. Тому можемо 
стверджувати, що зміст досліджуваного феномена визначатиметься специфічними характеристиками професійного спрямування та комунікативними потребами фахівців даного напряму підготовки.

Сучасна система підготовки товарознавців у ЗВО грунтується на галузевих стандартах вищої освіти (ГСВО) Міністерства освіти і науки України, які визначають освітньо-кваліфікаційні характеристики (ОКХ) випускників певних напрямів; установлює професійне призначення й умови використання спеціалістів, відображає мету й узагальнює зміст освіти і професійної підготовки в формі переліку умінь; виявляє місце й роль загальноосвітнього рівня й галузеві кваліфікаційні вимоги до випускника вишу. Освітньо-професійна програма (ОПП) є нормативною частиною змісту освіти, що установлює вимоги до змісту, обсягу, рівня освіти і професійної підготовки освітньо-кваліфікаційного рівня конкретної спеціальності.

Нині діяльність товарознавця потребує постійного росту через систематичне самовдосконалення, формування високого рівня розвитку та самореалізації [Корніяка, 2011: c. 187]. Отже, задля ефективного виконання професійної діяльності товарознавці повинні мати не лише інтегровані фахові знання та вміти їх використовувати, а й досконало володіти знаннями гуманітарного циклу, оскільки людина водночас є як суб'єктом, так і об'єктом нерозривно пов'язаного зі спілкуванням процесу управління.

Тому однією зі специфічних особливостей формування комунікативної компетентності в товарознавців постає взаємозв'язок гуманітарних i фахових дисциплін, оскільки знання й уміння конкретної спеціалізації не обмежуються одним спрямуванням.

Практика висуває до товарознавця такі професійні вимоги: конщептуальність - здібність адаптуватися до умов фірми, уміння масштабно мислити; оперативність - передбачає кваліфіковане розв'язання проблем; аналітичність - уміння ефективного використання аналітичних методів, діагностування проблем та визначення альтернативних рішень; комунікативність - уміння передавати ідеї усно та письмово; комунікабельність - здатність працювати з людьми, знаходити спільну мову в процесі спілкування [Касярум, 201: с. 12].

Майбутній товарознавець має володіти такою системою здатностей розв'язання проблем і завдань соціальної діяльності: засвоювати й реалізовувати наукові та культурні досягнення світової цивілізації у відношеннях до різних культур, загальнолюдських цін цінностей; критично оцінювати політичні, економічні події та явища; володіти державною й іноземною мовами на професійному рівні; засвоювати нові знання, прогресивні технології та інновації; бути здатним до ефективних комунікаційних взаємодій; системно розуміти внутрішній і зовнішній стан діяльності підприємства; розуміти витоки формування та інструментарій реалізації внутрішньої й зовнішньої політики держави; знати та виконувати норми національного й міжнародного законодавства, уміти захищати корпоративні права у відповідних інстанціях; знати загальноприйняті норми поведінки й моралі в міжособистісних відносинах; забезпечувати соціальну орієнтацію економічної діяльності організації [Савенкова, 2005: с. 17-19].

До професійних комунікативних здатностей відносимо такі: знання й уміння, що безпосередньо співвіднесені 3 фаховою підготовкою: орієнтування в інформаційному просторі та прогнозування алгоритмів організації пізнавального процесу; вміння планувати, передбачаючи наслідки професійної діяльності; 
прогнозування розвитку виробничої ситуації; володіння професійною компетентністю; аналіз змісту економічної діяльності. До особистісних комунікативних здатностей належать ті, що охоплюють здатності до здійснення професійно зорієнтованої комунікації, до яких належать: керування власною поведінкою; прагнення до самовдосконалення (самоосвіта, самопідготовка); комунікативна культура мислення та мовлення; творча конструктивна взаємодія учасників комунікативної діяльності на основі суб'єкт-суб' єктних відносин.

До загальних особливостей формування комунікативної компетентності майбутніх товарознавців відносимо такі: оволодіння культурою мислення та мовлення; окреслення професійно значущих якостей майбутніх товарознавців; наявність достатньо розвинутих фахових та особистісних здатностей відповідно до професійних функцій.

Специффічними особливостями формування комунікативної компетентності визначено: взаємозв'язок гуманітарних i фахових дисциплін у формуванні комунікативної компетентності; наявність уміння інтегрувати знання в систему категорій, що сприяють розвитку економічного мислення.

Висновки. Комунікативна компетентність товарознавців $є$ основою життєзабезпечення кожної організації, підприємства, являє живу тканину діяльності, потребує чіткого орієнтування у професійній ситуації, відбору тих засобів спілкування, які є найбільш ефективними.

Професійні якості, як мобільність, комунікабельність та діловитість майбутніх товарознавців, надзвичайно пов'язані з його професійною успішністю, яка виявляється в багатьох показниках, а саме: у професійній компетентності, постійному фаховому та особистісному зростанні.

Тому однісю зі специфічних особливостей формування комунікативної компетентності в товарознавців постає взаємозв'язок гуманітарних і фахових дисциплін, оскільки знання й уміння конкретної спеціалізації не обмежуються одним спрямуванням.

\section{ЛІТЕРАТУРА}

Великий тлумачний словник, 2005 - Великий тлумачний словник сучасної української мови (з дод. і доповн.) / [укл. і гол. ред. В. Т. Бусел]. - К.: Ірпінь : ВТФ «Перун», 2005. - 1728 с.

Касярум, 2015 - Касярум К.В. Комунікативна компетентність викладача вищої школи / К.В. Касярум // Наукова скарбниця освіти Донеччини. - 2015. - №2 (15). - С. 24-29.

Касярум, 2011 - Касярум К.В. Формування комунікативної компетенції магістрантів педагогічних спеціальностей у процесі фахової підготовки : автореф. дис. на здобуття наук. ступеня канд. пед. наук : спец. 13.00.04 - «теорія і методика професійної освіти» / К. В. Касярум; Черкас. нац. ун-т ім. Б. Хмельницького. - Черкаси, 2011. - 20 с.

Кічук, 2004 - Кічук Н. В. Ключові компетентності особистості фахівця як педагогічна проблема / Н. В. Кічук // Науковий вісник ПДПУ ім. К. Д. Ушинського : зб. наук. праць. - Одеса, 2004. - Вип. 8-9. Компетентнісна освіта: від теорії до практики / [Н. М. Бібік, І. Г. Єрмаков, О. В. Овчарук та ін.]. К. : Плеяди, 2005. - 120 с.

Корніяка, 2009 - Корніяка О. М. Сучасні підходи до вивчення комунікативної компетентності особистості / О. М. Корніяка // Проблеми сучасної психології : зб. наук. праць Кам'янець-Подільського нац. ун-ту ім. І. Огієнка, Ін-ту психології ім. Г. С. Костюка АПН України ; за ред. С. Д. Максименка, Л. А. Онуфрієвої. - Вип. 3. - Кам’янець-Подільський : Аксіома. - 2009. - С. 187-188.

Савенкова, 2005 - Савенкова Л.О. Професійне спілкування майбутніх викладачів як об'єкт психологопедагогічного управління: [монографія] / Л.О. Савенкова; Київ. нац. екон. ун-т ім. Вадима Гетьмана. - К. : КНЕУ, 2005. - 208 c. 


\section{REFERENCES}

Velykyi tlumachnyi slovnyk, 2005 - Velykyi tlumachnyi slovnyk suchasnoi ukrainskoi movy (z dod. i dopovn.) / ukl. i hol. red. V. T. Busel. - K.: Irpin : VTF «Perun», 2005. - 1728 s.

Kasiarum, 2015 - Kasiarum K.V. Komunikatyvna kompetentnist vykladacha vyshchoi shkoly / K.V. Kasiarum // Naukova skarbnytsia osvity Donechchyny. - 2015. - №2 (15). - S. 24-29.

Kasiarum, 2011 - Kasiarum K.V. Formuvannia komunikatyvnoi kompetentsii mahistrantiv pedahohichnykh spetsialnostei u protsesi fakhovoi pidhotovky : avtoref. dys. na zdobuttia nauk. stupenia kand. ped. nauk : spets. 13.00 .04 - «teoriia i metodyka profesiinoi osvity» / K. V. Kasiarum; Cherkas. nats. un-t im. B. Khmelnytskoho. - Cherkasy, 2011. $-20 \mathrm{c}$.

Kichuk, 2004 - Kichuk N. V. Kliuchovi kompetentnosti osobystosti fakhivtsia yak pedahohichna problema / N. V. Kichuk // Naukovyi visnyk PDPU im. K. D. Ushynskoho : zb. nauk. prats. - Odesa, 2004. - Vyp. 89. -Kompetentnisna osvita: vid teorii do praktyky / N. M. Bibik, I. H. Yermakov, O. V. Ovcharuk ta in..K. : Pleiady, 2005. - $120 \mathrm{~s}$.

Korniiaka, 2009 - Korniiaka O. M. Suchasni pidkhody do vyvchennia komunikatyvnoi kompetentnosti osobystosti / O. M. Korniiaka // Problemy suchasnoi psykholohii : zb. nauk. prats Kamianets-Podilskoho nats. un-tu im.

I. Ohiienka, In-tu psykholohii im. H. S. Kostiuka APN Ukrainy ; za red. S. D. Maksymenka, L. A. Onufriievoi. - Vyp. 3. - Kamianets-Podilskyi : Aksioma. - 2009. - S. 187-188.

Savenkova, 2005 - Savenkova L.O. Profesiine spilkuvannia maibutnikh vykladachiv yak obiekt psykholohopedahohichnoho upravlinnia: [monohrafiia] / L.O. Savenkova; Kyiv. nats. ekon. un-t im. Vadyma Hetmana. - K. : KNEU, 2005. - 208 s.

\section{УДК 378.011.3-051:74/76}

\author{
Віталій Форостюк, \\ викладач кафедри педагогіки, теорії та \\ методики початкової освіти \\ ДВНЗ «Переяслав-Хмельнииький \\ держсавний педагогічний університет \\ імені Григорія Сковороди».
}

DOI 10.31470/2308-5126-2019-45-2-141-147

\author{
Vitalii Forostyuk, \\ Lecturer of the Department of Pedagogy, \\ Theory and Methodology of Elementary \\ Education SHEI «Pereiaslav-Khmelnytskyi \\ Hryhorii Skovoroda \\ State Pedagogical University».
}

E-mail: forostiuk7@ gmail.com

ORCID 0000-0001-8511-0986

\section{ФОРМУВАННЯ ГОТОВНОСТІ МАЙБУТНЬОГО ВЧИТЕЛЯ ОБРАЗОТВОРЧОГО МИСТЕЦТВА ДО ТВОРЧОЇ ПЕДАГОГІЧНОЇ ДІЯЛЬНОСТІ}

\footnotetext{
У статті розглядається проблема формування готовності майбутнього вчителя образотворчого мистецтва до творчої педагогічної діяльності. Виокремлено важливі методи професійної підготовки майбутніх учителів. Висвітлено питання творчості, творчої активності. Доведено, що успішна підготовка майбутніх учителів залежить від використання ефективних методів $і$ технологій розвитку творчої особистості студентів образотворчого мистецтва, а також від сформованості їх творчої активності.

Аналізується сучасний зарубіжний $i$ вітчизняний досвід, наукові підходи щодо розв'язання проблеми. Звертається увага на методи, прийоми, особливості зарубіжної підготовки, які, на думку науковців, $є$ ефективними щзоо вирішення проблеми формування готовності майбутнього вчителя образотворчого мистецтва до творчої педагогічної діяльності. Пропонуються ефективні шляхи шодо вирімення актуальної проблеми сьогодення. Висвітлюється практичний досвід вирішення проблеми, який $є$ особливо важливим під час сучасних змін в освіті. Проаналізовано стан організації мистецької підготовки майбутніх учителів образотворчого мистечтва в сучасних закладах освіти.

Висвітлено специфіку діяльності вчителя образотворчого мистецтва, особливості фахової підготовки, наявності сформованих умінь і навичок. Здійснено аналіз педагогічних умов, за яких значно підвишується ефективність формування готовності майбутніх учителів образотворчого мистецтва до творчої педагогічної діяльності. Акцентується увага на доцільності впровадження в практику підготовки сучасного вчителя інновачійних методів, технологій, засобів та прийомів.

Ключові слова: готовність до педагогічної діяльності, творча діяльність, творча активність, майбутній учитель образотворчого мистеитва, освітній процес, педагогічний досвід.
} 